\title{
Subcutaneous Nodule
}

National Cancer Institute

\section{Source}

National Cancer Institute. Subcutaneous Nodule. NCI Thesaurus. Code C39618.

A small palpable mass in the subcutaneous tissues. 